\title{
The Moral Complexity of Agriculture: A Challenge for Corporate Social Responsibility
}

\section{Evelien M. de Olde ${ }^{1}$ (D) $\cdot$ Vladislav Valentinov $^{2}$}

Accepted: 3 June 2019 / Published online: 7 June 2019

(C) The Author(s) 2019

\begin{abstract}
Over the past decades, the modernization of agriculture in the Western world has contributed not only to a rapid increase in food production but also to environmental and societal concerns over issues such as greenhouse gas emissions, soil quality and biodiversity loss. Many of these concerns, for example those related to animal welfare or labor conditions, are stuck in controversies and apparently deadlocked debates. As a result we observe a paradox in which a wide range of corporate social responsibility (CSR) initiatives, originally seeking to reconnect agriculture and society, frequently provoke debate, conflict, and protests. In order to make sense of this pattern, the present paper contends that Western agriculture is marked by moral complexity, i.e., the tendency of multiple legitimate moral standpoints to proliferate without the realistic prospect of a consensus. This contention is buttressed by a conceptual framework that draws inspiration the contemporary business ethics and systems-theoretic scholarship. From the systems-theoretic point of view, the evolution of moral complexity is traced back to the processes of agricultural modernization, specialization, and differentiation, each of which suppresses the responsiveness of the economic and legal institutions to the full range of societal and environmental concerns about agriculture. From the business ethics point of view, moral complexity is shown to prevent the transformation of the ethical responsibilities into the legal and economic responsibilities despite the ongoing institutionalization of CSR. Navigating moral complexity is shown to require moral judgments which are necessarily personal and contestable. These judgments are implicated in those CSR initiatives that require dealing with trade-offs among the different sustainability issues.
\end{abstract}

Keywords Agriculture $\cdot$ Corporate social responsibility $\cdot$ Sustainability $\cdot$ Moral complexity $\cdot$ Systems theory

Evelien M. de Olde

evelien.deolde@wur.nl

1 Animal Production Systems Group, Wageningen University \& Research, Wageningen, The Netherlands

2 Leibniz Institute of Agricultural Development in Transition Economies, Halle, Germany 


\section{Introduction}

Modernization of European agriculture since the 1950s has contributed to a rapid increase in crop yields and livestock productivity. Since then, the number of farms have declined rapidly while those remaining have often specialized, increased in scale, intensified and mechanized (Bieleman 2008; Steinfeld et al. 2006). Although the process of modernization contributed to food security and affordable food in Europe, these developments have come at a cost. A major cost of agriculture results from its impact on the environment, e.g., through the emission of greenhouse gases and impact on biodiversity, water quality and air quality (Poore and Nemecek 2018; Springmann et al. 2018). Moreover, agriculture adds to the competition for natural resources including land, water, phosphorus and fossil fuel (Maroušek et al. 2019; Leip et al. 2015). Even the modern practices of on-farm production of renewable energy, for example from post-harvest residues (e.g. Maroušek 2013), instead of alleviating the competition, could potentially reinforce it, as these residues, along with other biomass, could be used for alternative purposes, such as improving soil quality or livestock feed (Van Zanten et al. 2018).

At the same time, societal developments including globalization, population growth, urbanization, increasing wealth, and changes in consumption behaviour [i.e. increase in the consumption of animal protein (Van Zanten et al. 2018)] have resulted in significant changes in the global food system (Porkka et al. 2013). Over the past 60 years, the global food system has moved from food insufficiency towards an increased dependency on food trade (Porkka et al. 2013). In 2017, the EU was the largest global exporter as well as importer of agri-food products (European Commission 2018). Such international trade of agricultural products results, however, in a shift of the environmental impact of agricultural production to other regions, also known as burden shifting (Lambin and Meyfroidt 2011; Clapp 2017). As such, it can affect local food security, public health and ecosystem services in these regions (Dalin and Rodríguez-Iturbe 2016; Muradian and Martinez-Alier 2001). The increasingly globalized market contributes to the disconnect between food production and food consumption. It separates consumers from recognizing the social and environmental impact of their dietary choices (Davis et al. 2016).

In addition to agriculture's environmental impact, concerns regarding the social impact of agricultural practices have been no less important (Van Assche et al. 2014; Thompson 2010). The increased awareness of possible public health risks related to agricultural production (e.g. living in proximity to farms (Clark and Soares Magalhães 2018; de Rooij et al. 2017), a range of food scandals (e.g. mad cow disease, dioxin, horse meat and fipronil) (Meijboom et al. 2006; van der Merwe et al. 2019) and the impact of farm practices on animal welfare have become issues of broad societal and political debate (Busch and Spiller 2018; Boogaard et al. 2011). Against this backdrop, both scholars and practitioners agree that agriculture is increasingly expected to account for its environmental and social impact (cf. Luhmann and Theuvsen 2017). In terms of Carroll's 
seminal (1991) pyramid of corporate social responsibility, this means that agricultural production has to comply not only with the economic and legal requirements, but also with the ethical responsibilities. As Bos et al. (2013, p. 71) put it, "the goal for agriculture is no longer simply to maximize productivity and profitability, but to optimize across a far more complex range of production, rural development, environmental, social and food consumption outcomes".

Corporate social responsibility (CSR) presents a premier channel through which farmers and agribusiness actors may discharge their ethical responsibilities (Luhmann and Theuvsen 2017). Producers and retailers are increasingly engaging in CSR initiatives in order to show their commitment to sustainability issues such as animal welfare and environment. Farmers are intensifying their efforts to monitor and report on the impact of their production on a wide range of sustainability issues (Boström et al. 2015; Whitehead 2016). In line with this development, the use of certification schemes for sustainable food products have increased rapidly (Mol and Oosterveer 2015; Brenton 2018). Other CSR initiatives from farmers (e.g. open days, school education) and retailers (e.g. commodity roundtables and market standards) are increasingly being organized (Rueda et al. 2017). The disconnect between farmer and consumer has made consumers increasingly dependent on such initiatives from producers and retailers to gain insight in how their food has been produced, based on what farming practices and values (Wiskerke 2009).

These important developments notwithstanding, the contribution of the present paper is in exploring the hypothesis that the potential of the agricultural CSR to resolve the numerous tensions between agriculture and society is inherently limited. This limit arises out of what is dubbed here as the moral complexity of agriculture. An issue may be taken to exhibit moral complexity if it is subject to moral controversies that do not converge toward a moral consensus (cf. Woermann 2013; Cillers 1998). If this definition is accepted, then many of the public concerns about agriculture are marked by a high degree of moral complexity. For example, animal welfare is a highly debated issue in which perspectives between stakeholders vary strongly (Busch and Spiller 2018; Te Velde et al. 2002). Housing systems (e.g. battery cage system for laying hens) and farming practices (e.g. debeaking, castration and dehorning) which were once developed to facilitate intensive livestock farming with high stocking densities, have likewise become increasingly controversial. Public demonstrations and legal actions against the construction of farm buildings, undercover videos from within stables and media campaigns from NGOs provide further examples of moral controversies that aggravate the tensions between certain groups in society and the agricultural sector (Stevens et al. 2018).

The key implication emerging from this hypothesis is that even though the agricultural CSR is not likely to lose any of its importance in the near future, it cannot be expected to generate a widespread moral consensus on the nature of the generally legitimate agriculture. While this implication may have reconciliatory effects on public debates, it can carry force only if its validity is argumentatively established. The scholarly task of the present paper is to develop the respective argument, illustrating thereby that the case of the agricultural CSR can be usefully demarcated from the much more general, and much more extensive, explorations of CSR in the business ethics scholarship. 
In order to explain why the condition of moral controversy is important for understanding the nature of the agricultural CSR, the present paper will build upon the social systems theory of Niklas Luhmann which has already gained some recognition in the multidisciplinary literature on farming systems (Kingwell 2011; Noe and Alrøe 2012; Darnhofer et al. 2012). Additionally to that, at a more basic level, this theoretical framework throws important sidelights on why the structural change in the Western agriculture poses ever more sustainability problems and is confronted with the growing moral pressures. In order to crystallize the core elements of this framework, the next sections will introduce a key Luhmannian argument that will be brought to bear on Carroll's (1991) CSR pyramid in such a way as to account for the case of moral complexity. The remaining sections present practical illustrations of these theoretic ideas. The example of the Netherlands will be used to show how the Luhmannian approach helps to make sense of the structural change in agriculture. The problems of some of the CSR initiatives, such as certification schemes and sustainability assessment tools, will be discussed by drawing on the secondary evidence from the parts of the North Western Europe and North America. We focus on these regions as they are marked by similar patterns of societal concerns and CSR initiatives (Busch and Spiller 2018). Furthermore, agriculture in these regions has been subject to somewhat less political violence than used to be the case in the Eastern Europe and other parts of the world. Accordingly, if Western agriculture exhibits moral complexity, then this complexity can be less plausibly attributed to extraneous influences, of political or other nature, while being much more likely indicative of the potentially precarious and disruptive relationship between agriculture and society as theorized e.g. by Thompson (2010).

\section{A Luhmannian Systems Theory Framework}

Drawing on Niklas Luhmann's wide-ranging scholarship, this chapter identifies the systems-theoretic arguments that are particularly suited for buttressing the case for the moral complexity of agriculture. Crystallizing these arguments is important because the Luhmannian systems theory seems to have had a somewhat limited influence on the business ethics literature (Valentinov 2019), whereas the systems theory more generally is commonly seen as an integrative approach that could bridge the social and technological dimension of agriculture, and even natural and social sciences (Jansen 2009). Systems theory provided an inspiration for agricultural scientists to undertake a more holistic and interdisciplinary approach (Jansen 2009; Darnhofer et al. 2012). It rose to prominence in farming systems research (FSR) which developed from the mid-seventies. FSR's point of departure was that the traditional approaches to agricultural yield had not only resulted in a boost in agricultural production but also gave rise to important public concerns about the impact of agricultural modernization on environmental and social issue. The impacts of technology-driven solutions on smallholders, the distribution of food and water, and food quality are cases in point (Bawden 1991; Schiere et al. 1999). FSR aimed to address the limitations of the reductionist approaches by applying a more holistic approach covering the importance of context, relations, and interactions (Schiere 
et al. 1999), thereby underlining the importance of involving multiple disciplines and stakeholders in the innovation process. Three key characteristics of FSR include the systems approach, interdisciplinarity and stakeholder participation (Darnhofer et al. 2012). In addition, systems theory has found its way into agricultural sciences through investigations of food systems and land systems (Darnhofer et al. 2012; Verburg et al. 2013).

Despite its ground-breaking systems-theoretic profile, Luhmann's work has until recently been a largely uncharted territory in the field of FSR. To fill this gap, Noe and Alrøe $(2015,2012,2003,2006)$ undertook a series of innovative attempts to enrich the field with the Luhmannian concepts, such as operational closure, autopoiesis, self-organization, and structural couplings. The authors conclude that "the sustainability crisis can be seen as a more or less unavoidable product of the processes of specialization, differentiation and decoupling that take place, and that the general societal development moves us away from perspectives that can observe and handle the complexity of a sustainable development of agriculture and food production" (Noe and Alrøe 2012, p. 401). This conclusion is likely to strike a chord with those commentators who see the general thrust of the Luhmannian systemstheoretic approach in the vision of the considerable precariousness of system-environment relations (e.g., Valentinov 2014; Valentinov et al. 2019; Will et al. 2018). It seems that this precariousness originates essentially from what Luhmann referred to as "the complexity gap" between the system and its outer environment.

To make sense of this gap, it is useful to recall that Luhmann located the general function of social systems in complexity reduction which helps human individuals possessing limited cognitive capacities to orientate themselves in the exceedingly complex social and natural environment. By reducing the environmental complexity, social systems alleviate the cognitive burden on the individuals. In doing so, social systems themselves ignore a major chunk of what is happening in the environment which logically turns out to be infinitely more complex than any individual system. The systems are thus confronted with the challenge of maintaining themselves "against the overwhelming complexity of the environment" (Luhmann 1995, p. 182). This challenge can be met by those systems that sufficiently reduce their sensitivity to the environment, primarily through the mechanism of operational closure which Luhmann contrasted with the concept of systemic openness advanced by Ludwig von Bertalanffy (1968). Operationally closed systems "produce not only their structures, but also the elements of which they consist in the network of these same elements" (Luhmann 2012, p. 76 et seq).

Even though Luhmann can hardly be said to have been paradigmatically concerned with the present-day agenda of sustainable development, his systems-theoretic concepts, such as the precariousness of system-environment relations, complexity reduction, and operational closure contain implicit cues about the nature of the persisting sustainability problems. Some of these cues have been rendered explicit in Valentinov's (2014) conceptual construct of the "complexity-sustainability tradeoff". The construct consists of two principles, dubbed as complexity reduction and critical dependence. The former principle "posits that systems increase their complexity by becoming increasingly insensitive to the complexity of the environment", whereas according to the latter principle "the increasing complexity of systems is 
associated with their growing dependence on environmental complexity in ways that make the continuation of their autopoiesis increasingly unlikely" (ibid, p. 18). Put together, the principles explain why "the growing systemic complexity entails the increasing risk that systems develop insensitivity to those environmental conditions on which they critically depend" (ibid, p. 14).

The premier type of social systems in which Luhmann took central interest is the function systems, such as economy, law, politics, and science. Luhmann saw the key feature of the modern society in its decomposition into these and other function systems which are operationally closed and limitedly sensitive to their outer environment. He described, for example, the operational closure of the economy in terms of its being "rigorously closed, circular, self-referentially constituted system because it effects payments that presuppose the capacity for making payments... Thus money is a unique economic medium. It cannot be introduced as input from nor transmitted as output into the environment. Its exclusive task is to mediate system-internal operations" (Luhmann 1989, p. 52). To Luhmann (ibid), the operational closure of the economy as well as other function systems in the modern society presents a major explanation of the ongoing ecological crisis, an explanation which is in line with the widespread acknowledgment of the maladaptation of the economy and the society as a whole to the conditions of their natural environment. Applying this argument to the business ethics context, Valentinov et al. (2019) conjectured that the same operational closure probably accounts for the problem of the pervasive business-society tensions in the West.

Assuming the modern society to consist of the function systems structurally coupled to each other, Luhmann rejected the classical sociological view of social integration on the basis of shared values and moral norms. He took the regime of functional differentiation to be essentially amoral, i.e., unrelated to the considerations of moral rightness or wrongness. At the same time, he acknowledged the existence in the modern society of what he called moral communication which is centered around the expression of respect on contempt for individual persons (Luhmann 1993). He believed however that this communication is more likely to cause conflicts rather than to solve problems because most problems of the modern society are systemic rather than individual (ibid). Moral philosophy is accordingly called upon to "warn against" this conflict potential and thus to take a more distanced attitude to morality as its subject matter (ibid). Despite Luhmann's own reservations, it seems clear that the problems of sustainability can often be classed as systemic and are often discussed in moral terms. The relationship between morality and the systemic nature of the modern society remains one of the most controversial elements in Luhmann's legacy. The next chapter disentangles some of these elements by turning attention to Carroll's (1991) seminar CSR pyramid.

\section{Revisiting Archie Carroll's CSR Pyramid}

Archie Carroll's (1991) pyramid remains one of the most popular conceptual approaches to CSR in the contemporary business ethics literature (cf. Carroll 2016; Carroll and Buchholtz 2014; Schwartz and Carroll 2003; Luhmann and Theuvsen 
2017). The pyramid differentiates between the economic, legal, ethical, and philanthropic corporate responsibilities. Whereas the economic and legal responsibilities are "required by society", the ethical ones are "expected by society", and the philanthropic ones are merely "desired" (Carroll 2016, p. 5). Schwartz and Carroll (2003) note that the pyramid has been subject to several misunderstandings related, among other things, to the meaning of the pyramidal structure, to the nature of the discretionary philanthropic responsibilities, and to the incomplete conceptualization of the economic, legal, and ethical responsibilities. To dispel these misunderstandings, Schwartz and Carroll (2003) develop a Venn model framework highlighting the core domains of the economic, legal, and ethical responsibilities as well as the overlaps between them. Applying the original pyramid to the German agribusiness context, (Luhmann and Theuvsen 2017) likewise suggest a major modification by replacing Carroll's (1991) four types of responsibilities by the following three: economic, internal to the firm, and external to the firm.

An interesting feature of Carroll's (1991) pyramid is its remarkable consistence with the Luhmannian systems-theoretic vision of the functional differentiation of society. Recent commentators on Luhmann noted that the economic and legal responsibilities of corporations are usefully thought of as reflecting corporate involvement in the function systems of the economy and law, whereas the existence of the additional ethical and philanthropic responsibilities illustrates the embeddedness of these function systems in the broader societal environment which must be likewise considered by corporations (Will et al. 2018; Gagalyuk et al. 2018). The demarcation line between the lower and upper halves of the pyramid can thus be taken to highlight the "complexity gap" engendering much of the precariousness of business-society tensions, especially given the limited sensitivity of social systems, including both function systems and corporations, to their outer environment (ibid). Yet, in the business ethics context, it seems clear that this demarcation line is continually expanding. Carroll (1991, p. 41) himself argues that "the business ethics movement of the past decade ... is constantly pushing the legal responsibility category to broaden or expand". Referring to the context of Eastern Europe, Gagalyuk et al. (2018) note that the insecure and imperfect institutions of the economic and legal systems result in the increasing importance of the upper half of the pyramid, especially for large corporations such as agroholdings. Bowen's (1953) landmark study of CSR likewise refers to the processes of ongoing institutionalization which increasingly convert the societal expectations of ethical corporate behavior into the formal legal framework of corporate activity. If the ongoing institutionalization of CSR indeed results in the continual expansion of the legal and economic responsibilities, then more needs to be known on how the boundary between the legal and economic function systems and their outer environment is maintained over time in the business context.

As explained above, Luhmann traced the reproduction of this boundary back to the operational closure and the limited sensitivity of social systems to their outer environment. In the business ethics context, this argument translates into the acknowledgement of the unpredictability, radical uncertainty, and turbulence of the business environment faced by corporations. The role of turbulence of the business environment takes center stage in Freeman et al.'s (2010) seminal justification of 
the stakeholder approach which challenges "the mainstream view of shareholder capitalism" (Freeman et al. 2010, p. xv). As Freeman et al. (2010) make clear, if turbulence is growing, corporations cannot engage in the sustainable long-run profit maximization without fostering trustful relationships with stakeholders. Jones et al. (2018) locate the key elements of this turbulence in "environmental dynamism, knowledge intensity, and task and outcome interdependence". Furthermore the processes of institutionalization analyzed by Bowen (1953) suffer from substantial implementation problems which weaken the problem-solving potential of many institutional reform proposals (Jones and Felps 2013). If turbulence is high and institutional reform is difficult, then the boundary between the lower and upper halves of Carroll's (1991) pyramid will not be able to shift too far.

The recent evolution of agriculture in Northwestern Europe suggests a further important limit to the institutionalization of CSR and to the expansion of the range of the economic and legal responsibilities of corporations. This limit is the condition of moral complexity reflecting the lack of moral consensus on a wide variety of issues which remain the subject of hot public debates. Evidently, the accommodation of specific responsibilities into the formal legal institutional work must be democratically legitimated on the basis of the broad political support. The state of moral complexity is precisely what renders such legitimation impossible. Accordingly, an essential difference between the ethical responsibilities, on the one hand, and the economic and legal responsibilities, on the other, is that the latter have gone through a democratic legitimation procedure while the former are not subject to this requirement. In his controversial book Capitalism and Freedom, Friedman (1962) objected to the corporate pursuit of any social objectives by showing these objectives to be needful of democratic legitimation that is achievable only through political institutions. Now, the state of moral complexity in the Western agriculture puts Friedman's (ibid) argument on its head. Moral complexity means that quite a number of societal expectations directed toward agriculture are marked by a high degree of moral legitimacy but are far from converging on any consensus. Given that the democratic legitimacy needed for the full-fledged institutionalization of these expectations cannot be secured, the only option for taking them seriously is through the CSR initiatives, and especially those initiatives that may classed under the rubric of "ethical responsibilities". Thus, in the context of the Western agriculture, the state of moral complexity turns out to be a powerful mechanism for maintaining the boundary between the functions systems, such as those of the economy and law, and their outer societal environment. Some of the practical workings of this mechanism are illustrated in the following section.

\section{Illustrations}

\section{Structural Change in the Western Agriculture: The Dutch Case}

As in other Western countries, agriculture in the Netherlands had transformed rapidly in the past decades. While in 1950 the country had 410,000 farms, in 2015 only $16 \%(64,000)$ remained (CBS 2018). Farms not only declined in numbers, they also 
specialized. Of the 410,000 farms in $1950,53 \%$ had cattle, $66 \%$ pigs, and $70 \%$ had poultry. In other words, many farms were mixed. In $2015,45 \%$ of the total number of farms had cattle, $8 \%$ pigs and only $3 \%$ keep poultry (laying hens or broilers) (CBS 2018). This process of horizontal differentiation separated agricultural production into different branches (Noe and Alrøe 2012). Many farms specialized even more by focusing on specific phases of livestock production (e.g. parental stock, rearing of young hens, or laying hens). The process of specialization of operations into autonomous organizations (which can be recognized both on-farm as well as in the food chain) is referred to as vertical differentiation (Noe and Alrøe 2012).

While the number of farms declined, the numbers of animals remained rather constant or increased, resulting in an upscaling. If we for example look at the dairy sector, on average the number of dairy cows increased from 7 in 1950, to 35 in 1980 and to 89 in 2015 (Bieleman 2008; CBS 2017). Milk production per animal increased too from $3944 \mathrm{~kg}$ per year to 5030 in 1980 and 8219 in 2015 (ibid). Especially in the last 15 years, a rapid upscaling can be observed, also in terms of cultivated land per dairy farm with on average 28 ha in 2000, and 46 ha in 2015 (CBS 2019). The upscaling is often financed through an increase in long-term loans (CBS 2016). Meanwhile the number of fulltime farm workers hardly increased over this time period (from 2.0 to 2.1) resulting in more animals per labour unit (from 29 to 43) (Agrimatie 2017). This intensification was amongst other things facilitated by an increase in mechanization including the use of the tractors and the milking machines (Bieleman 2008). This development was also strongly driven by the strong increase in wage levels (index $1950=100,1985=2400$ ). Moreover, farmers were encouraged to invest in mechanization and supported by suppliers of seeds, artificial fertilizers and concentrates.

The main thrust of these structural change patterns is well aligned with the evolutionary implications of the Luhmannian "complexity-sustainability trade-off" (Valentinov 2014; Noe and Alrøe 2012). First and foremost, modernization of agriculture resulted in the management of larger and more specialized farms with an increased dependency on external inputs, i.e., with more severe critical dependencies. As farm size and yields increased, the importance of farm management to maintain or even improve yields, limit pests and diseases, and managing relations with suppliers of inputs and services, contributed to an increased internal complexity of farming systems (Kingwell 2011; Noe and Alrøe 2012). Moreover, constantly changing farming conditions including changes in bio-physical properties (e.g. soil degradation, compaction), climate, market prices, laws and regulations, market requirements as well as a farmer's individual characteristics (family, succession, social dynamics) add to the complexity of farming systems and of the implementation of innovations (Darnhofer et al. 2012). Finally, the dynamics involved in the implementation of innovations (De Olde et al. 2016a) and new technologies [for example to address nutrient management (Maroušek et al. 2017)] likewise adds to this complexity.

In view of the limited cognitive capacities of the individual human mind, it is natural to expect that the growing internal complexity of farming systems necessitates more effective complexity reduction instruments, such as those exemplified by the processes of horizontal and vertical differentiation and specialization (Noe and Alrøe 2012). By reducing the complexity of consecutive and parallel operations, 
these instruments permit a production system to focus on optimizing internal performance (Noe and Alrøe 2012). As explained by the complexity-sustainability tradeoff, the side-effect of these mechanisms is the reduction of the production system's sensitivity to the environment and thus the relative disregard for environmental externalities and societal concerns (Valentinov 2014). Meanwhile, agriculture fully retains its critical dependencies on its environment for its production conditions provided by soil, water, air, nutrients and pollinators, and for its consumption by society.

For example, in the area of egg production, the vertical differentiation taking the form of the increasing number of links in the chain has resulted in the de-coupling between egg producers and consumers as eggs are predominantly sold in supermarkets where they have been delivered to by egg packing centres. A good example of the similar effects of the horizontal differentiation comes from the specialized pig or poultry farmers who buy their feed from the feed industry and no longer have to be concerned about the production of animal feed and its underlying processes of maintaining soil fertility, biodiversity, and nutrient cycles, which are of critical importance for the long term sustainability of agriculture (Noe and Alrøe 2012). The upshot of these examples is that the increase in the number of links in the chain leads undermines the previously existing (direct) feedback mechanisms between producers and consumers. As Noe and Alrøe (2012, p. 400) put it, "farm businesses seemingly have to worry less and less about what consumers think, because the relation with the consumers are more left to the processors, and even increasingly to the retailers using private labels".

\section{Moral Complexity as a Challenge for CSR}

The decoupling of producers and consumers, and of producers to the environment is increasingly recognized and results in a wide variety of initiatives. The meaning of moral complexity is that many these of these initiatives do not converge on a common understanding of what Carroll (1991, p. 42) referred to as "right, just, and fair". For example, in Denmark as well as in other western European countries, some farmers, often supported by their processor, organize open days for citizens to visit the farm. In Denmark, on the annual Økodag approximately $4 \%$ of the Danish population visit an organic dairy farm to see the cows going outside for the first day of the spring. Yet, a certain number of protesters likewise find their way to the farms to protest against dairy production outside of the farm gates. Or, consider the case of the Twitter account 'Boerburgertweet' (translated as Farmer-citizen tweet) that has been initiated in 2015 in the Netherlands by a communication specialist active in the agricultural sector. Every week, a different farmer is asked to showcase her or his daily work (using pictures and videos) in order to inform the consumers about how the food is being produced. The Twitter account currently has 11,060 followers, and on Facebook it has 18,907 followers (28-03-2019). Yet, sharing this information has led in some cases to fierce debates, conflicts or even threats between farmers and citizens who hold opposing perspectives on what is ethical (Stevens et al. 2018; Tijhaar 2017). In fact, the 
prevalent conceptions of rightness, justice, and fairness were for many decades focused on producing more, while reducing the amount of labour and resources critically needed to enable low food prices for consumers, and ensure a fair income for farmers. What is increasingly considered as ethical now is a significant break from this rationale. While economic and legal laws are clearly defined, the definition of the ethical responsibilities involving the conceptions of fairness, justice, and rightness (Carroll 1991) is notoriously more problematic. The only thing that can be safely said about this definition is that it has to emerge from the continuous societal debate reflecting different perceptions, including values, norms, convictions, interest and knowledge (Te Velde et al. 2002). This debate, however, cannot be assumed to generate consensual solutions with any degree of certainty. The lack of consensus is particularly dramatic in the livestock production, where perceptions on what is just, right, and fair vary strongly and often eventuate in conflicts, for example, when opposing stakeholders meet online (Te Velde et al. 2002; Stevens et al. 2018).

Consider the case of retailers seeking to improve animal welfare conditions in broiler production by means of slower growing broilers (Lusk 2018). It is clear that such initiatives for improving animal welfare conditions will not be recognized as ethical by those who consider consuming meat to be unethical. Moreover, as slower growing broilers require more resources including feed (which could partly be consumed by humans as well), some argue that this production is not ethical in terms of resource use either. These are just casual illustrations of the more general fact of the existence of trade-offs between many ethical issues. A similar state of moral complexity is characteristic of many other debates related to truth, justice, and sustainability. As stated by Bell and Morse (2008, p. 11) "My justice may be your exploitation, and my truth may be your lies!" Thus, whereas Carroll (1991) characterized the upper half of the CSR pyramid in terms of what is "desired" and "expected" rather than "required" by society, a proper characterization in the agricultural context would be in terms of what is "hotly debated" without the prospect of a consensus.

Yet, even if this prospect is not forthcoming, getting such debates off the ground requires a fair amount of effort related to taking account of the evolving values and interests (Meadowcroft 2007; Bell and Morse 2008). For example, CSR initiatives aiming to address sustainability concerns must take a stand on a variety of aspects, such as which sustainability issues to focus on, which indicators to use to measure the impact on these issues, and what levels of performance to consider as good or bad for sustainability (i.e. which reference values to set). In the selection of issues and indicators, the choice of criteria is often decisive. As argued by Rueda et al. (2017) the awareness of consumer and civil society can play an important role in defining which issues to address. Animal welfare, for example, has a prominent position in the CSR activities of retailers (Croney et al. 2018; Lever and Evans 2017). This attention can come at the expense of other sustainability issues. "While supermarkets support the development of new markets for animal welfare friendly products (Miele and Lever 2013) in partnership with NGOs in some instances (Miele and Lever 2014), their power is such that they continue to exploit nature and the workers producing such products (Gouveia and Juska 2002; Lawrence 2012; Lever and Milbourne 2015)" (Lever and Evans 2017, p. 218). Hence, as follows from the condition 
of moral complexity, trade-offs among sustainability issues need to be carefully considered as improvement on one issue can have an adverse effect on another.

Furthermore, research shows that the selection of sustainability indicators is influenced by criteria such as affordability, time requirement, precision, sensitivity, quantification, ease to communicate and data availability (De Olde et al. 2016b). As a result of such criteria, for example quantification, indicators that are less easy to quantify, especially social issues, often receive less attention (Binder et al. 2010). How to balance such criteria for selecting indicators thus remains an issue of dispute, even among sustainability experts (De Olde et al. 2016b) who often prefer different sets of indicators for sustainability assessment. Today, a large number of sustainability assessment tools have been developed for assessing the sustainability performance of farms, for example for the purposes of certification, self-assessment, or policy development (Schader et al. 2014). A comparison of several integral sustainability assessment tools showed that even when these tools have a similar scope, their outcomes can vary as a result of the differences in the way the tools are developed (De Olde et al. 2017). Some of these differences are related to assessment methods, indicator selection, reference values (i.e. what is taken to be good/bad performance), aggregation and scoring methods (De Olde et al. 2017). As a result, it is small wonder that the tools provide different conclusions on the sustainability performance of specific farms. This raises concerns regarding the reliability and validity of the tools for the purposes such as certification (cf. Van Assche et al. 2014; Van Assche and Hornidge 2015).

Meanwhile, consumers, on their part, expect 'objective' reporting on the impact of primary products on sustainability issues such as greenhouse gas emissions, biodiversity and animal welfare. Yet, another manifestation of moral complexity of agriculture is in the fact that the translation of the concept of sustainable development into a tool or standard is not possible without value judgements (Röös et al. 2014). As Owens (2003, p. 7) put it, "probably any attempt to move beyond Brundtland's consensual but vague definition... would raise not only scientific questions, but profound ethical and political dilemmas". In addition, the governance of sustainable supply chains is challenged by gaps related to the availability of reliable information, implementation problems, power relations, and credibility and legitimacy of certification (Boström et al. 2015). As transparency and monitoring of certification schemes is limited, concerns arise as to their genuine contribution to a continual improvement towards sustainable development (ibid).

\section{Concluding Remarks}

The paradoxical yet recurrent pattern of the agriculture in the West is that the wide range of CSR initiatives, originally seeking to reconnect agriculture and society, frequently provoke debate, conflict, and protests (van Lieshout et al. 2011; Stevens et al. 2018). Another pattern is that many of the societal and environmental concerns engendered by the ongoing radical and dramatic structural change are stuck in controversies and apparently deadlocked debates. These patterns provide the essential empirical inspiration for the hypothesis that the apparent failure of CSR initiatives 
to resolve the numerous tensions between agriculture and society is due to the state of moral complexity as a premier character of Western agriculture. In practical terms, understanding the moral complexity of agriculture, and thus the affirmation of the above hypothesis, is important for appreciating the momentous, if not insuperable, challenges faced by those agricultural producers who make genuine efforts to meet societal expectations. In order to justify the hypothesis in theoretical terms, the present paper develops a conceptual framework that captures some of the essential business ethics dimensions of the ongoing structural change processes. From the business ethics point of view, the key characteristic of these processes is moral complexity which can be understood as the proliferation of legitimate moral controversies without the realistic prospect of a consensus. The meaning of moral complexity is explicated on the basis of the integration of Carroll's (1991) CSR pyramid and a Luhmannian systems-theoretic framework. Farms are shown to be crucially involved in the legal and economic function systems, but must nevertheless face up to the ethical responsibilities which go beyond the limits of the operational closure of the function systems. Moral complexity is indicated as one essential reason why, despite the ongoing institutionalization of CSR, the economic and legal responsibilities associated with the economic and legal function systems fail to do justice to the full range of the societal and environmental concerns about agriculture.

Part of the novelty of the conceptual framework developed in the paper originates from the unconventional interpretation of both Carroll's (1991) pyramid and Luhmann's systems-theoretic approach. Carroll's (1991) classification of responsibilities is reinforced by the fact of the proliferating moral complexity which prevents the ongoing institutionalization of CSR from covering every moral implication of agriculture. This argument inverts the logic of Friedman's (1962) reasoning about the need to shift CSR to the institutions of the political system which meet the test of democratic legitimacy. The state of moral complexity precludes this legitimacy and is qualified for farm-level CSR for precisely this reason. Luhmann's systemstheoretic approach is in turn enriched by a more nuanced understanding of moral communication. Whereas Luhmann considered moral communication to be excessively person-centered and conflictual, the proposed conceptual framework opens up the possibility that this communication may include moral judgments which present the essential means for navigating moral complexity. Absent moral judgments could indeed paralyze individual action just as much as the unfiltered and unreduced environmental complexity could do so. Moral judgments are furthermore often implicated in the compromises and trade-offs involved in specific CSR initiatives such as sustainability certification. Compromises are needed to navigate the tradeoffs among sustainability issues, to select relevant indicators, to define meaningful reference values all the while dealing with different perspectives of stakeholders involved.

Furthermore, the proposed conceptual framework sheds novel light on Luhmann's controversial assumption about the dysfunctional nature of the person-centeredness of morality. Moral judgments are inevitably personal. Accordingly, many improvements in the sustainability performance of farms (e.g. lowering greenhouse gas emissions, efforts to maintain biodiversity, protection of water and soil and improving animal welfare) result from farmers' personal moral judgments endorsing 
ethical farming. This sort of person-centeredness may indeed be out of synch with the systemic nature of social reality, as Luhmann supposed, for the judgments and efforts of individual farmers often remain unseen and unvalued as their products are jointly collected and sold anonymously. These efforts therefore are generally not directly translated to (financial) benefits and could disappear unless these are driven by intrinsic motivation or are part of a CSR initiative such as specific label, certification or retailer' requirements. Overcoming this sort of person-centeredness of moral judgments indeed presents a major challenge for CSR in agriculture, both conceptually and practically.

Acknowledgements The first author thankfully acknowledges financial support from the Leibniz Institute of Agricultural Development in Transition Economies (IAMO). The second author gratefully acknowledges the support of the German Research Society.

Open Access This article is distributed under the terms of the Creative Commons Attribution 4.0 International License (http://creativecommons.org/licenses/by/4.0/), which permits unrestricted use, distribution, and reproduction in any medium, provided you give appropriate credit to the original author(s) and the source, provide a link to the Creative Commons license, and indicate if changes were made.

\section{References}

Agrimatie. (2017). Arbeidsinzet en-productiviteit melkveehouderij. https://www.agrimatie.nl/SectorResu ltaat.aspx?subpubID=2232\&sectorID=2245\&themaID=2264. Accessed 28 Mar 2019.

Bawden, R. J. (1991). Systems thinking and practice in agriculture. Journal of Dairy Science, 74(7), 2362-2373. https://doi.org/10.3168/jds.S0022-0302(91)78410-5.

Bell, S., \& Morse, S. (2008). Sustainability indicators: Measuring the immeasurable?. London: Earthscan.

Bieleman, J. (2008). Boeren in Nederland. Geschiedenis van de landbouw 1500-2000: Boom.

Binder, C. R., Feola, G., \& Steinberger, J. K. (2010). Considering the normative, systemic and procedural dimensions in indicator-based sustainability assessments in agriculture. Environmental Impact Assessment Review, 30(2), 71-81.

Boogaard, B. K., Boekhorst, L. J. S., Oosting, S. J., \& Sørensen, J. T. (2011). Socio-cultural sustainability of pig production: Citizen perceptions in the Netherlands and Denmark. Livestock Science, 140(1-3), 189-200. https://doi.org/10.1016/j.livsci.2011.03.028.

Bos, J. F. F. P., Smit, A. L., \& Schröder, J. J. (2013). Is agricultural intensification in The Netherlands running up to its limits? NJAS-Wageningen Journal of Life Sciences, 66, 65-73. https://doi. org/10.1016/j.njas.2013.06.001.

Boström, M., Jönsson, A. M., Lockie, S., Mol, A. P. J., \& Oosterveer, P. (2015). Sustainable and responsible supply chain governance: Challenges and opportunities. Journal of Cleaner Production, 107, 1-7. https://doi.org/10.1016/j.jclepro.2014.11.050.

Bowen, H. R. (1953). Social responsibilities of the businessman. New York: Harper \& Brothers.

Brenton, S. (2018). (Political) Consumers and certification schemes: The ethics of global production and trade. Journal of Agricultural and Environmental Ethics, 31(6), 755-784. https://doi.org/10.1007/ s10806-018-9754-3.

Busch, G., \& Spiller, A. (2018). Consumer acceptance of livestock farming around the globe. Animal Frontiers, 8(1), 1-3. https://doi.org/10.1093/af/vfx005.

Carroll, A. B. (1991). The pyramid of corporate social responsibility: Toward the moral management of organizational stakeholders. Business Horizons, 34(4), 39-48.

Carroll, A. B. (2016). Carroll's pyramid of CSR: Taking another look. International Journal of Corporate Social Responsibility, 1(1), 3. https://doi.org/10.1186/s40991-016-0004-6.

Carroll, A. B., \& Buchholtz, A. K. (2014). Business and society: Ethics, sustainability, and stakeholder management: Cengage learning. 
CBS. (2016). Veel vreemd vermogen in tuinbouw. https://www.cbs.nl/nl-nl/achtergrond/2016/03/veelvreemd-vermogen-in-tuinbouw. Accessed 24 Mar 2019.

CBS. (2017). Grotere melkveebedrijven en meer melk. https://www.cbs.nl/nl-nl/nieuws/2017/18/groteremelkveebedrijven-en-meer-melk\#id=undefined. Accessed 24 Mar 2019.

CBS. (2018). Landbouw; vanaf 1851. Den Haag/Heerlen: Centraal Bureau voor de Statistiek.

CBS. (2019). Landbouw; gewassen, dieren en grondgebruik naar bedrijfstype, nationaal. Den Haag/ Heerlen: Centraal Bureau voor de Statistiek.

Cillers, P. (1998). Complexity and postmodernism: Understanding complex systems. London: Routledge.

Clapp, J. (2017). Food self-sufficiency: Making sense of it, and when it makes sense. Food Policy, 66, 88-96. https://doi.org/10.1016/j.foodpol.2016.12.001.

Clark, N. J., \& Soares Magalhães, R. J. (2018). Airborne geographical dispersal of Q fever from livestock holdings to human communities: A systematic review and critical appraisal of evidence. BMC Infectious Diseases, 18(1), 218. https://doi.org/10.1186/s12879-018-3135-4.

Croney, C., Muir, W., Ni, J.-Q., Widmar, N. O., \& Varner, G. (2018). An overview of engineering approaches to improving agricultural animal welfare. Journal of Agricultural and Environmental Ethics, 31(2), 143-159. https://doi.org/10.1007/s10806-018-9716-9.

Dalin, C., \& Rodríguez-Iturbe, I. (2016). Environmental impacts of food trade via resource use and greenhouse gas emissions. Environmental Research Letters, 11(3), 035012.

Darnhofer, I., Gibbon, D., \& Dedieu, B. (2012). Farming systems research: An approach to inquiry. In I. Darnhofer, D. Gibbon, \& B. Dedieu (Eds.), Farming systems research into the 21st century: The new dynamic (pp. 3-31). Dordrecht: Springer.

Davis, K. F., Gephart, J. A., Emery, K. A., Leach, A. M., Galloway, J. N., \& D’Odorico, P. (2016). Meeting future food demand with current agricultural resources. Global Environmental Change, 39, 125-132. https://doi.org/10.1016/j.gloenvcha.2016.05.004.

De Olde, E. M., Bokkers, E. A. M., \& De Boer, I. J. M. (2017). The choice of the sustainability assessment tool matters: differences in thematic scope and assessment results. Ecological Economics, 136, 77-85. https://doi.org/10.1016/j.ecolecon.2017.02.015.

De Olde, E. M., Carsjens, G. J., \& Eilers, C. H. A. M. (2016a). The role of collaborations in the development and implementation of sustainable livestock concepts in The Netherlands. International Journal of Agricultural Sustainability. https://doi.org/10.1080/14735903.2016.1193423.

De Olde, E. M., Moller, H., Marchand, F., McDowell, R. W., MacLeod, C. J., Sautier, M., et al. (2016b). When experts disagree: the need to rethink indicator selection for assessing sustainability of agriculture. Environment, Development and Sustainability. https://doi.org/10.1007/s10668-016-9803-x.

de Rooij, M. M. T., Heederik, D. J. J., Borlée, F., Hoek, G., \& Wouters, I. M. (2017). Spatial and temporal variation in endotoxin and PM10 concentrations in ambient air in a livestock dense area. Environmental Research, 153, 161-170. https://doi.org/10.1016/j.envres.2016.12.004.

European Commission (2018). Monitoring Agri-trade Policy. MAP 2018-1. (p. 26). Brussels, Belgium: European Commission, Agriculture and Rural Development.

Freeman, R. E., Harrosin, J. S., Wicks, A. C., Parmar, B., \& de Colle, S. (2010). Stakeholder theory: The state of the art. Cambridge: Cambridge University Press.

Friedman, M. (1962). Capitalism and freedom. Chicago: The University of Chicago Press.

Gagalyuk, T., Valentinov, V., \& Schaft, F. (2018). The Corporate Social Responsibility of Ukrainian Agroholdings: the Stakeholder Approach Revisited. Systemic Practice and Action Research, 31(6), 675-698. https://doi.org/10.1007/s11213-018-9448-9.

Gouveia, L., \& Juska, A. (2002). Taming nature, taming workers: Constructing the separation between meat consumption and meat production in the U.S. Sociologia Ruralis, 42(4), 370-390.

Jansen, K. (2009). Implicit sociology, interdisciplinarity and systems theories in agricultural science. Sociologia Ruralis, 49(2), 172-188. https://doi.org/10.1111/j.1467-9523.2009.00486.x.

Jones, T. M., \& Felps, W. (2013). Shareholder wealth maximization and social welfare: A utilitarian critique. Business Ethics Quarterly, 23(2), 207-238. https://doi.org/10.5840/beq201323215.

Jones, T. M., Harrison, J. S., \& Felps, W. (2018). How applying instrumental stakeholder theory can provide sustainable competitive advantage. Academy of Management Review, 43(3), 371-391. https:// doi.org/10.5465/amr.2016.0111.

Kingwell, R. (2011). Managing complexity in modern farming. Australian Journal of Agricultural and Resource Economics, 55(1), 12-34. https://doi.org/10.1111/j.1467-8489.2010.00528.x.

Lambin, E. F., \& Meyfroidt, P. (2011). Global land use change, economic globalization, and the looming land scarcity. Proceedings of the National Academy of Sciences, 108(9), 3465-3472. https://doi. org/10.1073/pnas.1100480108. 
Lawrence, F. (2012). Workers who collected freedom food chickens 'were trafficked and beaten'. The Guardian, Monday, October 29. Accessed 2 Dec 2015.

Leip, A., Billen, G., Garnier, J., Grizzetti, B., Lassaletta, L., Reis, S., et al. (2015). Impacts of European livestock production: nitrogen, sulphur, phosphorus and greenhouse gas emissions, land-use, water eutrophication and biodiversity. Environmental Research Letters, 10(11), 115004.

Lever, J., \& Evans, A. (2017). Corporate social responsibility and farm animal welfare: Towards sustainable development in the food industry? In S. O. Idowu \& S. Vertigans (Eds.), Stages of corporate social responsibility: From ideas to impacts (pp. 205-222). Cham: Springer.

Lever, J., \& Milbourne, P. (2015). The structural invisibility of outsiders: The role of migrant labourin the meat-processing industry. Sociology. https://doi.org/10.1177/0038038515616354.

Luhmann, N. (1989). Ecological communication. Chicago: The University of Chicago Press.

Luhmann, N. (1993). Gesellschaftsstruktur und semantik (Vol. 3). Frankfurt am Main: Suhrkamp.

Luhmann, N. (1995). Social systems. Stanford: Stanford University Press.

Luhmann, N. (2012). Theory of society (Vol. 1). Palo Alto: Stanford University Press.

Luhmann, H., \& Theuvsen, L. (2017). Corporate social responsibility: Exploring a framework for the agribusiness sector. Journal of Agricultural and Environmental Ethics, 30(2), 241-253. https:// doi.org/10.1007/s10806-017-9665-8.

Lusk, J. L. (2018). Consumer preferences for and beliefs about slow growth chicken. Poultry Science, 97(12), 4159-4166. https://doi.org/10.3382/ps/pey301.

Maroušek, J. (2013). Study on commercial scale steam explosion of winter brassica Napus STRAW. International Journal of Green Energy, 10(9), 944-951. https://doi.org/10.1080/15435 075.2012.732158.

Maroušek, J., Kolář, L., Vochozka, M., Stehel, V., \& Maroušková, A. (2017). Novel method for cultivating beetroot reduces nitrate content. Journal of Cleaner Production, 168, 60-62. https://doi. org/10.1016/j.jclepro.2017.08.233.

Maroušek, J., Stehel, V., Vochozka, M., Kolář, L., Maroušková, A., Strunecký, O., et al. (2019). Ferrous sludge from water clarification: Changes in waste management practices advisable. Journal of Cleaner Production, 218, 459-464.

Meadowcroft, J. (2007). Who is in charge here? Governance for sustainable development in a complex world. Journal of Environmental Policy and Planning, 9(3-4), 299-314. https://doi. org/10.1080/15239080701631544.

Meijboom, F. L. B., Visak, T., \& Brom, F. W. A. (2006). From trust to trustworthiness: Why information is not enough in the food sector. Journal of Agricultural and Environmental Ethics, 19(5), 427-442. https://doi.org/10.1007/s10806-006-9000-2.

Miele, M., \& Lever, J. (2013). Civilizing the market for welfare friendly products in Europe? The techno-ethics of the Welfare Quality Assessment. Geoforum, 48, 63-72.

Miele, M., \& Lever, J. (2014). Improving animal welfare in Europe: Cases of comparative bio-sustainabilities. In T. Marsden, \& A. Morely (Eds.), Sustainable food systems: Building a new paradigm. London: Earthscan.

Mol, A. P. J., \& Oosterveer, P. (2015). Certification of markets, markets of certificates: Tracing sustainability in global agro-food value chains. Sustainability, 7(9), 12258.

Muradian, R., \& Martinez-Alier, J. (2001). Trade and the environment: from a 'Southern' perspective. Ecological Economics, 36(2), 281-297. https://doi.org/10.1016/S0921-8009(00)00229-9.

Noe, E., \& Alrøe, H. F. (2003). Farm enterprises as self-organizing systems: A new transdisciplinary framework for studying farm enterprises? International Journal of Sociology of Agriculture and Food, 11(1), 3-14.

Noe, E., \& Alrøe, H. F. (2006). Combining Luhmann and actor-network theory to see farm enterprises as self-organizing systems. Cybernetics and Human Knowing, 13(1), 34-48.

Noe, E., \& Alrøe, H. F. (2012). Observing farming systems: Insights from social systems theory. In I. Darnhofer, D. Gibbon, \& B. Dedieu (Eds.), Farming systems research into the 21st century: The new dynamic (pp. 387-403). Dordrecht: Springer.

Noe, E., \& Alrøe, H. F. (2015). Sustainable agriculture issues explained by differentiation and structural coupling using social systems analysis. Agronomy for Sustainable Development, 35(1), 133-144. https://doi.org/10.1007/s13593-014-0243-4.

Owens, S. (2003). Is there a meaningful definition of sustainability? Plant Genetic Resources: Characterization and Utilization, 1(01), 5-9.

Poore, J., \& Nemecek, T. (2018). Reducing food's environmental impacts through producers and consumers. Science, 360(6392), 987-992. https://doi.org/10.1126/science.aaq0216. 
Porkka, M., Kummu, M., Siebert, S., \& Varis, O. (2013). From Food Insufficiency towards trade dependency: A historical analysis of global food availability. PLoS One, 8(12), e82714. https://doi. org/10.1371/journal.pone.0082714.

Röös, E., Ekelund, L., \& Tjärnemo, H. (2014). Communicating the environmental impact of meat production: Challenges in the development of a Swedish meat guide. Journal of Cleaner Production, 73, 154-164. https://doi.org/10.1016/j.jclepro.2013.10.037.

Rueda, X., Garrett, R. D., \& Lambin, E. F. (2017). Corporate investments in supply chain sustainability: Selecting instruments in the agri-food industry. Journal of Cleaner Production, 142, 2480-2492. https://doi.org/10.1016/j.jclepro.2016.11.026.

Schader, C., Grenz, J., Meier, M. S., \& Stolze, M. (2014). Scope and precision of sustainability assessment approaches to food systems. Ecology and Society. https://doi.org/10.5751/es-06866-190342.

Schiere, J. B., Lyklema, J., Schakel, J., \& Rickert, K. G. (1999). Evolution of farming systems and system philosophy. Systems Research and Behavioral Science, 16(4), 375-390.

Schwartz, M. S., \& Carroll, A. B. (2003). Corporate social responsibility: A three-domain approach. Business Ethics Quarterly, 13(4), 503-530.

Springmann, M., Clark, M., Mason-D'Croz, D., Wiebe, K., Bodirsky, B. L., Lassaletta, L., et al. (2018). Options for keeping the food system within environmental limits. Nature, 562(7728), 519-525. https ://doi.org/10.1038/s41586-018-0594-0.

Steinfeld, H., Gerber, P., Wassenaar, T., Castel, V., Rosales, M., \& Haan, C. D. (2006). Livestock's long shadow: environmental issues and options. Rome: Food and Agriculture Organization of the United Nations (FAO).

Stevens, T. M., Aarts, N., Termeer, C. J. A. M., \& Dewulf, A. (2018). Social media hypes about agrofood issues: Activism, scandals and conflicts. Food Policy, 79, 23-34. https://doi.org/10.1016/j. foodpol.2018.04.009.

Te Velde, H., Aarts, N., \& Van Woerkum, C. (2002). Dealing with ambivalence: Farmers' and Consumers' perceptions of animal welfare in livestock breeding. Journal of Agricultural and Environmental Ethics, 15(2), 203-219. https://doi.org/10.1023/A:1015012403331.

Thompson, P. B. (2010). The agrarian vision: Sustainability and environmental ethics. Lexington: The University of Kentucky Press.

Tijhaar, B. (2017). Boerenaccount gekaapt door activisten: 'Ze worden vergeleken met Hitler'. De Stentor.

Valentinov, V. (2014). The complexity-sustainability trade-off in Niklas Luhmann's social systems theory. Systems Research and Behavioral Science, 31(1), 14-22. https://doi.org/10.1002/sres.2146.

Valentinov, V. (2019). The ethics of functional differentiation: reclaiming morality in Niklas Luhmann's social systems theory. Journal of Business Ethics, 155(1), 105-114. https://doi.org/10.1007/s1055 1-017-3521-7.

Valentinov, V., Roth, S., \& Will, M. G. (2019). Stakeholder theory: A Luhmannian perspective. Administration and Society, 51(5), 826-849. https://doi.org/10.1177/0095399718789076.

Van Assche, K., Beunen, R., \& Duineveld, M. (2014). Evolutionary governance theory: An introduction. New York: Springer.

Van Assche, K., \& Hornidge, A. K. (2015). Rural development: Knowledge and expertise in governance. Wageningen: Wageningen Academic Publishers.

van der Merwe, D., Jordaan, A., \& van den Berg, M. (2019). Case report: Fipronil contamination of chickens in the Netherlands and surrounding countries. In Chemical hazards in foods of animal origin (pp. 363-373): Wageningen Academic Publishers.

van Lieshout, M., Dewulf, A., Aarts, N., \& Termeer, C. (2011). Do scale frames matter? Scale frame mismatches in the decision making process of a "Mega Farm" in a small Dutch village. Ecology and Society, 16(1), 38. http://www.ecologyandsociety.org/vol16/iss1/art38/.

Van Zanten, H. H. E., Herrero, M., Van Hal, O., Röös, E., Muller, A., Garnett, T., et al. (2018). Defining a land boundary for sustainable livestock consumption. Global Change Biology, 24(9), 4185-4194. https://doi.org/10.1111/gcb.14321.

Verburg, P. H., Erb, K.-H., Mertz, O., \& Espindola, G. (2013). Land System Science: Between global challenges and local realities. Current Opinion in Environmental Sustainability, 5(5), 433-437. https://doi.org/10.1016/j.cosust.2013.08.001.

von Bertalanffy, L. (1968). General system theory: Foundations, development, applications. New York: George Braziller. 
Whitehead, J. (2016). Prioritizing sustainability indicators: Using materiality analysis to guide sustainability assessment and strategy. Business Strategy and the Environment. https://doi.org/10.1002/ bse. 1928.

Will, M. G., Roth, S., \& Valentinov, V. (2018). From nonprofit diversity to organizational multifunctionality: A systems-theoretical proposal. Administration and Society, 50(7), 1015-1036. https://doi. org/10.1177/0095399717728093.

Wiskerke, J. S. C. (2009). On places lost and places regained: Reflections on the alternative food geography and sustainable regional development. International Planning Studies, 14(4), 369-387. https:// doi.org/10.1080/13563471003642803.

Woermann, M. (2013). On the (im)possibility of business ethics: Critical complexity, deconstruction, and implications for understanding the ethics of business. New York: Springer.

Publisher's Note Springer Nature remains neutral with regard to jurisdictional claims in published maps and institutional affiliations. 